\title{
Paenibacillus lactis sp. nov., isolated from raw and heat-treated milk
}

\author{
Correspondence \\ Patsy Scheldeman \\ P.Scheldeman@clo.fgov.be
}

\author{
Patsy Scheldeman, ${ }^{1}$ Karen Goossens, ${ }^{1,2} \dagger$ Marina Rodriguez-Diaz, ${ }^{3}$ \\ Annelies Pil, ${ }^{1,2} \ddagger$ Johan Goris, ${ }^{2} \S$ Lieve Herman, ${ }^{1}$ Paul De Vos, ${ }^{2}$ \\ Niall A. Logan ${ }^{3}$ and Marc Heyndrickx ${ }^{1}$
${ }^{1}$ Ministry of the Flemish Community, Centre for Agricultural Research, Department of Animal Product Quality, Brusselsesteenweg 370, 9090 Melle, Belgium
${ }^{2}$ Universiteit Gent, Faculty of Sciences, Laboratory of Microbiology (WE10V), K. L. Ledeganckstraat 35, 9000 Gent, Belgium
${ }^{3}$ Glasgow Caledonian University, School of Biological and Biomedical Sciences, Cowcaddens Road, Glasgow G4 OBA, UK

Published online ahead of print on 5 December 2003 as DOI 10.1099/ ijs.0.02822-0.

tPresent address: Laboratory of Animal Genetics, Ghent University, Heidestraat 19, 9820 Merelbeke, Belgium.

$\ddagger$ Present address: Department of Bacteriology and Immunology, Veterinary and Agrochemical Research Centre, VAR-CODA-CERVA, Groeselenberg 99, 1180 Ukkel, Belgium.

$\S$ Present address: Center for Microbial Ecology, Michigan State University, 545 Plant and Soil Science Building, East Lansing, MI 488241325, USA.

Abbreviations: ARDRA, amplified rDNA restriction analysis; FAME, fatty acid methyl ester.

The GenBank/EMBL/DDBJ accession numbers for the 16S rRNA gene sequences of $P$. lactis MB 1871 ${ }^{\top}$, MB 1928, MB 2035 and Paenibacillus sp. MB 2039 are respectively AY257868-AY257871.

Detailed strain information, DNA-DNA relatedness and $\mathrm{G}+\mathrm{C}$ content data, a full phylogenetic tree and a photomicrograph of sporangia and vegetative cells of the type strain are available as supplementary material in IJSEM Online.
Paenibacillus strains have been isolated from a variety of sources including soil, the rhizosphere, water, diseased insect larvae and foods (Daane et al., 2002) and display physiologically diverse characteristics. One distinctive characteristic of members of the genus is their ability to degrade a variety of macromolecules, amongst others proteins (Ash et al., 1993), polysaccharides (Kanzawa et al., 1995; Claus \& Berkeley, 1986) and polyaromatic hydrocarbons (Daane et al., 2002). Another is the ability of paenibacilli associated with plants to fix nitrogen. These include Paenibacillus azotofixans (Seldin et al., 1984), Paenibacillus polymyxa (Grau \& Wilson, 1962) and Paenibacillus macerans (Witz et al., 1967). More recently, four more nitrogen-fixing species of Paenibacillus, Paenibacillus borealis (Elo et al., 2001), Paenibacillus brasilensis (von der Weid et al., 2002), Paenibacillus graminis and Paenibacillus odorifer (Berge et al., 2002), have been described. Some Paenibacillus strains also produce antibacterial (e.g. Martin et al., 2003; Piuri et al., 1998) or antifungal compounds (e.g. Beatty \& Jensen, 2002; Chung et al., 2000). 
Sporogenesis enables members of Bacillus, Paenibacillus and related organisms to withstand environmentally harsh conditions, allowing long-term survival (Setlow, 1994). The resulting omnipresence of Bacillus and its relatives favours contamination of many foods. The resistance of their endospores, which may be associated with psychrophilic or acidophilic properties of the vegetative cells, causes specific problems to the food industry (Andersson et al., 1995). Incidences of paenibacilli in food products such as pasteurized puréed vegetables have been reported previously (Berge et al., 2002; Guinebretière et al., 2001). The most common spore-forming bacteria (55\% of the isolates) found in the production process of refined paper products for food applications proved to be Paenibacillus species (Raaska et al., 2002).

Although Paenibacillus spores in raw and pasteurized milk are not predominant, their presence has been recognized (for an overview, see Heyndrickx \& Scheldeman, 2002). Feeds for dairy cattle appear to be a significant source of contamination of raw milk with spores. Paenibacillus species are present in both silage (te Giffel et al., 2002) and feed concentrate for dairy cattle (Vaerewijck et al., 2001). To our knowledge, there have been no previous reports of Paenibacillus spores surviving industrial sterilization or UHT processing of milk. Nevertheless, te Giffel et al. (2002) reported that some Paenibacillus spores were able to withstand temperatures above $120^{\circ} \mathrm{C}$.

In this study, we elucidated the taxonomic position of 19 spore-formers isolated from contaminated industrial UHT milk and from the dairy farm. In addition to molecular typing, we used extensive phenotypic characterization, $16 \mathrm{~S}$ rRNA gene sequencing and DNA-DNA reassociation to study these isolates.

Details of the strains included in this study are listed in Supplementary Table A available in IJSEM Online. All strains, except for LMG $11157^{\mathrm{T}}$ and SB150-2B, were isolated after a 30 -min $100{ }^{\circ} \mathrm{C}$ heat treatment of the samples, either from a number of dairy farms (Scheldeman et al., 2002) or from contaminated UHT milk from different processing lines in a dairy plant. All MB-numbered strains were grown on brain heart infusion (BHI; Oxoid) supplemented with bacteriological agar no. 1 (Oxoid) and filter-sterilized vitamin $\mathrm{B}_{12}\left(1 \mathrm{mg} \mathrm{l}^{-1}\right.$; Sigma). The type strain of Paenibacillus lautus, LMG $11157^{\mathrm{T}}$, was grown according to the recommendations of the BCCM/LMG Bacteria Culture Collection.

Whole-cell DNA for PCR amplification was extracted from pure cultures by the method described by Pitcher et al. (1989). For DNA-DNA reassociation experiments, highquality total genomic DNA was purified on a larger scale as described by Logan et al. (2000), except that lysozyme was dissolved in TE buffer with an increased EDTA concentration $(1 \cdot 21 \mathrm{~g}$ Tris, $6 \mathrm{ml} 0 \cdot 5 \mathrm{M} \mathrm{EDTA}$, $\mathrm{pH} 8 \cdot 0$, in 1 MilliQ water) and that the cell suspensions were incubated with lysozyme until the viscosity increased (usually after 10-15 min).
In this study, the term rep-PCR is used as an overall term to refer to molecular typing based on repetitive elements [including REP-, (GTG) $5_{5^{-}}$, BOX- and ERIC-PCR], whereas REP-PCR refers to one specific method using the primers REP 1R-I and REP 2-I (Versalovic et al., 1994). The conditions for REP-PCR were described previously by Herman et al. (1998). In addition, the (GTG) $)_{5}$ primer (Versalovic et al., 1994) was used under the following PCR conditions. Amplification reactions were performed in a final volume of $25 \mu \mathrm{l}$ containing PCR buffer ( $10 \mathrm{mM}$ Tris/ $\mathrm{HCl}, \mathrm{pH} 8 \cdot 3$, and $50 \mathrm{mM} \mathrm{KCl}$ ) (Applied Biosystems), $1.5 \mathrm{mM} \mathrm{MgCl}_{2}, 0 \cdot 2 \mathrm{mM}$ of each dNTP (Pharmacia), $0 \cdot 3 \mu \mathrm{g}$ primer, $1 \mathrm{U}$ Goldstar DNA polymerase (Eurogentec) and 25 ng DNA template. The PCR program (Versalovic et al., 1994) was run on a DNA thermal cycler (Perkin Elmer 9600). To avoid inter-PCR differences, all samples were included in one single PCR run.

The rep-PCR amplicons were separated in a $1.5 \%$ LSI LE agarose gel (Life Science International) $(20 \times 25 \mathrm{~cm})$ for $4 \mathrm{~h}$ at a constant voltage of $4 \mathrm{~V} \mathrm{~cm}^{-1}$ in $1 \times$ TBE $(100 \mathrm{mM}$ Tris/ $\mathrm{HCl}, 100 \mathrm{mM}$ boric acid, $2 \mathrm{mM}$ EDTA, $\mathrm{pH}$ 8・0). repPCR profiles were visualized after staining with ethidium bromide, followed by digital image capturing using a GelDoc 2000 camera (Bio-Rad). A mixture of molecular mass markers VIII, IX and X (Roche) was used as references for intra- and inter-gel comparison. Numerical analysis of the resulting fingerprints was done using the GelCompar II version 2.0 software package (Applied Maths). Similarity among digitized profiles was calculated using Pearson's correlation coefficient and an average linkage (UPGMA) dendrogram was derived. Finally, both the REP- and (GTG) ${ }_{5}$-PCR patterns were linearly combined, assigning the same weight to each analysis.

Amplified rDNA restriction analysis (ARDRA) of $16 \mathrm{~S}$ rDNA was performed as described previously (Heyndrickx et al., 1996).

The 16S rRNA genes of strains MB $1871^{\mathrm{T}}\left(=\mathrm{LMG} 21940^{\mathrm{T}}=\right.$ DSM $\left.15596^{\mathrm{T}}\right)$, MB 1928 and MB 2035 were amplified by PCR using conserved primers pA (5'-AGAGTTTGATCCTGGCTCAG-3') and pH (5'-AAGGAGGTGATCCAGCCGCA- $\left.3^{\prime}\right)$. The PCR products were purified and subsequently sequenced using an ABI 310 sequencer (Applied Biosystems) as described previously (Scheldeman et al., 2002). A combination of primers $\mathrm{pA},{ }^{\star} \mathrm{pD},{ }^{\star} \mathrm{O},{ }^{\star} \mathrm{R},{ }^{\star}$ gamma and $\mathrm{pH}$ (Coenye et al., 1999) was used to obtain a continuous stretch of the $16 \mathrm{~S}$ rRNA gene sequence. Sequence assembly was implemented using the GeneBase software (Applied Maths). The BioNumerics 3.0 software package (Applied Maths) was used for construction of a phylogenetic tree based on the neighbour-joining method.

DNA-DNA hybridizations were performed with photobiotin-labelled probes in microplate wells as described by Ezaki et al. (1989). For the fluorescence measurements, a Bio Assay Reader (HTS7000, Perkin Elmer) was used as described in detail by Willems et al. (2001). A hybridization 
temperature of $37^{\circ} \mathrm{C}$ was applied for the experiments in this study.

The DNA base composition was determined by HPLC using further specifications given by Logan et al. (2000).

The culture conditions for fatty acid methyl ester (FAME) analysis were as described by Scheldeman et al. (2002). The methods used for fatty acid extraction, methyl ester preparation and separation by GC were described by Vancanneyt et al. (1996).

Phenotypic tests were performed as described by Logan \& Berkeley (1984); other characters were determined and the data numerically analysed as described by Logan et al. (2000). For observations on sporangia, cells were grown on TSA $\mathrm{MnSO}_{4}$ at $30^{\circ} \mathrm{C}$.

During a period of obstinate contamination of the UHTmilk production in a dairy company, two colony types were isolated from nine individual packages from different processing lines (both direct and indirect UHT). The first colony type, present in only two samples, resembled Bacillus sporothermodurans and was indeed identified as such by the PCR-detection method described by Herman et al. (1997) (data not shown). Isolates of the second colony type, present in all nine samples, reacted negatively both to the latter PCR detection method and to the more universal PCR test of Scheldeman et al. (2002), based on the 16S rDNA of $B$. sporothermodurans. The contamination of the UHT-milk packages was therefore due to another spore-forming organism, present in co-contamination with B. sporothermodurans and probably also surviving the UHT process.

The 16S rRNA gene sequence of one of the nine non- $B$. sporothermodurans UHT isolates, MB 1928, was determined and the highest similarity in the EMBL database found by a FASTA search (Pearson \& Lipman, 1988) was $97.0 \%$ (1432 nt overlap) to Paenibacillus sp. SB-150-2B (=MB 2328; AF395029), a strain isolated from an ice core in Sajama, Bolivia. The highest similarity to a recognized species was only $96.6 \%$, to P. lautus NRRL NRS- $666^{\mathrm{T}}$ (D78473; $1396 \mathrm{nt}$ overlap). However, the 16S rRNA gene of strain MB 1928 did show a pairwise similarity of $99 \cdot 1 \%$ to MB 2035 (=R-6472), a strain isolated from raw milk during a survey for very heat-resistant spore-forming bacteria on dairy farms in 1999 (Scheldeman et al., 2002).

In addition to MB 2035 and MB 2328 (=SB-150-2B), more close relatives of the fresh-UHT isolate MB 1928 were sought among a large collection of strains on the basis of their wholecell FAME profiles (data not shown) and a selection of representative strains was subsequently subjected to ARDRA (data not shown). In ARDRA, the raw-milk strain MB 2035 grouped together with three other strains, MB $1868(=\mathrm{R}-6435), \mathrm{MB} 1871^{\mathrm{T}}\left(=\mathrm{R}-7191^{\mathrm{T}}\right)$ and $\mathrm{MB} 1879$ ( = R-7193), with a similarity of $95 \%$ (data not shown). Based on the FAME data, 15 other potentially related Paenibacillus strains from dairy farms (see Table 1), grouping within an
Euclidian distance of 15 from the above-mentioned strains, were selected for polyphasic characterization.

Repetitive element-based genomic fingerprinting (repPCR) was used to assess the diversity of the selected strains mentioned in Supplementary Table A. From a cluster analysis based on combined REP and (GTG) $)_{5}$ fingerprints, combined with a visual examination of the banding patterns, five clusters (designated A-E in Fig. 1) could be delineated. The nine UHT isolates and one farm strain isolated from a cluster of the milking apparatus (MB 1868) all grouped together in cluster B at an internal similarity of $92 \cdot 1 \%$. Interestingly, all these isolates showed virtually identical banding patterns and could thus be regarded as of clonal origin. A group of nine farm isolates grouped together in a more diverse cluster $\mathrm{A}$, at a similarity level of $62 \cdot 4 \%$. The remainder of the strains grouped together in three smaller clusters. Cluster C, with an internal similarity of $56.9 \%$, contained four raw milk strains, whereas cluster D consisted of a raw milk strain and a farm strain grouping together at $63.6 \%$. Three strains originating from the milking apparatus of the same farm grouped together in cluster $\mathrm{E}$ at a similarity level of $72 \cdot 7 \%$. Finally, the ice-core strain MB 2328 took a single position in the dendrogram.

Although clusters A and B showed a mutual similarity of only $34 \cdot 4 \%$, common bands between these two groups could be observed [particularly in the (GTG) $)_{5}$ fingerprints].

Table 1. Cellular fatty acid composition of strain MB $1871^{\top}$ and some other species of the genus Paenibacillus

Strains: 1, P. lactis sp. nov. MB $1871^{\mathrm{T}} ; 2$, Paenibacillus sp. MB 2039; 3, P. lautus NRRL NRS-666 ${ }^{\mathrm{T}} ; 4$, P. glucanolyticus DSM $5162^{\mathrm{T}}$; 5, P. macerans JCM $2500^{\mathrm{T}}$; 6, P. polymyxa JCM $2507^{\mathrm{T}}$. Values are percentages of total fatty acids. Data for reference strains (columns 3-6) were taken from Shida et al. (1997). ND, Not detected.

\begin{tabular}{|lrrrrrc|}
\hline Fatty acid & $\mathbf{1}$ & $\mathbf{2}$ & $\mathbf{3}$ & $\mathbf{4}$ & $\mathbf{5}$ & $\mathbf{6}$ \\
\hline Saturated fatty acids & & & & & & \\
$\mathrm{C}_{14: 0}$ & $0 \cdot 9$ & $0 \cdot 8$ & $1 \cdot 1$ & $0 \cdot 8$ & $3 \cdot 7$ & $0 \cdot 4$ \\
$\mathrm{C}_{15: 0}$ & $2 \cdot 7$ & $6 \cdot 6$ & $0 \cdot 3$ & $0 \cdot 7$ & $0 \cdot 5$ & $0 \cdot 3$ \\
$\mathrm{C}_{16: 0}$ & $9 \cdot 7$ & $9 \cdot 2$ & $15 \cdot 6$ & $11 \cdot 2$ & $17 \cdot 9$ & $9 \cdot 3$ \\
$\mathrm{C}_{17: 0}$ & $0 \cdot 6$ & $1 \cdot 6$ & $\mathrm{ND}$ & $\mathrm{ND}$ & $\mathrm{ND}$ & $\mathrm{ND}$ \\
Unsaturated fatty acids & & & & & & \\
$\mathrm{C}_{16: 1} \omega 7 c$ alcohol & $0 \cdot 6$ & $\mathrm{ND}$ & $\mathrm{ND}$ & $\mathrm{ND}$ & $\mathrm{ND}$ & $\mathrm{ND}$ \\
$\mathrm{C}_{16: 1} \omega 11 c$ & $4 \cdot 2$ & $\mathrm{ND}$ & $2 \cdot 0$ & $0 \cdot 5$ & $0 \cdot 1$ & $\mathrm{ND}$ \\
Branched fatty acids & & & & & & \\
iso-C $\mathrm{C}_{14: 0}$ & $1 \cdot 2$ & $1 \cdot 7$ & $0 \cdot 8$ & $1 \cdot 4$ & $7 \cdot 9$ & $0 \cdot 5$ \\
iso- $\mathrm{C}_{15: 0}$ & $11 \cdot 5$ & $8 \cdot 4$ & $1 \cdot 5$ & $3 \cdot 2$ & $2 \cdot 6$ & $1 \cdot 0$ \\
iso- $\mathrm{C}_{16: 0}$ & $6 \cdot 7$ & $13 \cdot 5$ & $7 \cdot 4$ & $13 \cdot 9$ & $16 \cdot 4$ & $5 \cdot 6$ \\
iso- $\mathrm{C}_{17: 0}$ & $5 \cdot 6$ & $5 \cdot 4$ & $1 \cdot 2$ & $2 \cdot 0$ & $0 \cdot 6$ & $1 \cdot 6$ \\
anteiso- $\mathrm{C}_{15: 0}$ & $45 \cdot 9$ & $44 \cdot 5$ & $57 \cdot 3$ & $56 \cdot 5$ & $36 \cdot 1$ & $62 \cdot 9$ \\
anteiso- $\mathrm{C}_{17: 0}$ & $9 \cdot 6$ & $8 \cdot 3$ & $9 \cdot 7$ & $8 \cdot 2$ & $12 \cdot 2$ & $16 \cdot 9$ \\
iso- $\mathrm{C}_{17: 0} \omega 10 c$ & $0 \cdot 9$ & $\mathrm{ND}$ & $0 \cdot 2$ & $0 \cdot 2$ & $\mathrm{ND}$ & $\mathrm{ND}$ \\
\hline
\end{tabular}


(GTG) $)_{5}-\mathrm{PCR}$

$\% \quad 20, \quad 40, \quad 60, \quad 80, \quad 100$

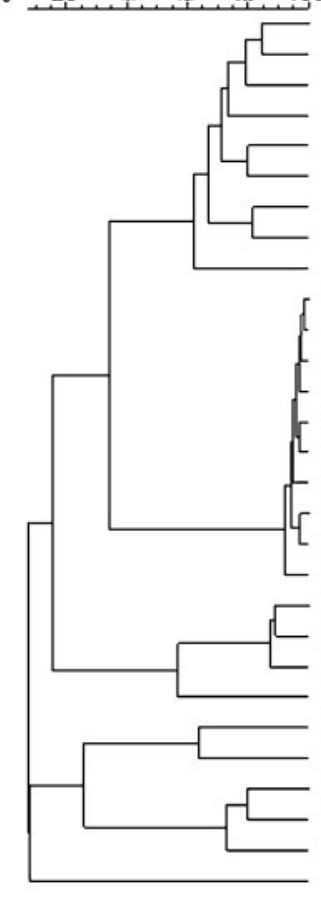

REP-PCR



Fig. 1. Clustering of Paenibacillus strains, isolated from UHT milk and from dairy farms, based on linearly combined REP- and $(\mathrm{GTG})_{5}-\mathrm{PCR}$ fingerprints and calculated with the UPGMA algorithm and Pearson's correlation coefficient. The isolation source of the strains is given in parentheses. More detailed strain information is available in Supplementary Table A.

This observation fitted with the observation that strains $\mathrm{MB}$ 2035 from cluster A and MB 1928 from cluster B showed over $99 \%$ similarity in their $16 \mathrm{~S}$ rRNA gene sequences. An additional $16 \mathrm{~S}$ rDNA sequence of another strain from the more heterogeneous cluster $\mathrm{A}, \mathrm{MB} 1871^{\mathrm{T}}$, was determined and found to be 99.5 and $99.6 \%$ similar to the $16 \mathrm{~S}$ rDNA of MB 1928 and MB 2035, respectively. In contrast, the 16S rDNA sequence from a raw milk strain from cluster $\mathrm{C}$ (Fig. 1), MB 2039, showed only $91 \cdot 1 \%$ similarity to the $16 \mathrm{~S}$ rDNA of MB 1928. As a result, the strains of cluster C can not be considered as phylogenetically closely related to strains of clusters A and B.

Comparison of the 16S rDNA sequences of strains $\mathrm{MB}$ $1871^{\mathrm{T}}, \mathrm{MB} 1928$ and MB 2035 with those of all recognized species of the genus Paenibacillus is given in a phylogenetic neighbour-joining tree (Fig. 2; see also Supplementary Fig. A). The three strains MB $1871^{\mathrm{T}}, \mathrm{MB} 1928$ and MB 2035 showed mutual $16 \mathrm{~S}$ rDNA similarities of over $99 \%$ and they appeared as a well-separated branch in the phylogenetic tree (Fig. 2), with P. lautus JCM $9073^{\mathrm{T}}$ (approx. 97\% 16S rDNA similarity), Paenibacillus sp. SB-150-2B (approx. $97 \%$ ) and Paenibacillus glucanolyticus DSM $5162^{\mathrm{T}}$ (approx. $96 \%)$ as their closest relatives.

The status of the three strains MB $1871^{\mathrm{T}}$, MB 1928 and MB 2035 was further confirmed by genomic DNA-DNA reassociation



Fig. 2. Neighbour-joining tree, derived from 16S rDNA sequences, showing the phylogenetic positions of Paenibacillus lactis sp. nov. strains and the type strains of recognized Paenibacillus species. GenBank accession numbers are given and bootstrap values (expressed as percentages of 1000 replications) are shown at branch points when higher than $70 \%$. Unknown bases were not considered for the analysis. Bar, $2 \%$ sequence divergence. The tree from which this tree was derived is available as Supplementary Fig. A. 
studies (for detailed results, see Supplementary Table B). Strain MB $1871^{\mathrm{T}}$ showed 90 and $79 \%$ DNA-DNA relatedness with strains MB 2035 and MB 1928, respectively. The latter two strains showed $79 \%$ mutual DNA-DNA relatedness. Moreover, the DNA-DNA relatedness of these three strains with $P$. lautus $\mathrm{LMG} 11157^{\mathrm{T}}$, as well as with strain MB 2328, was generally low (20-25\%). The ice-core strain MB 2328 is clearly related to $P$. lautus, as evidenced by a high DNA reassociation value (62\%; Supplementary Table B) as well as a high $16 \mathrm{~S}$ rDNA sequence similarity of $99 \cdot 6 \%$ with the $P$. lautus type strain. The representative strains MB $1871^{\mathrm{T}}, \mathrm{MB} 1928$ and MB 2035 and the other 16 strains of the REP and (GTG) $)_{5}$ clusters A and $\mathrm{B}$ can therefore be considered as belonging to a novel species of the genus Paenibacillus (Wayne et al., 1987; Stackebrandt et al., 2002). The usefulness of rep-PCR for delineating groups of strains for taxonomic purposes was also demonstrated in previous studies (e.g. Rademaker et al., 2000; Goris et al., 2002). The status of the novel strains is also corroborated by their DNA base composition (Supplementary Table B), which falls within the range $45-54 \mathrm{~mol} \% \mathrm{G}+\mathrm{C}$, as reported for the genus Paenibacillus (Shida et al., 1997).

In the cellular fatty acid analysis (Table 1), a predominance of anteiso-C $C_{15: 0}$, typical of paenibacilli (Shida et al., 1997), was also observed for $\mathrm{MB} 1871^{\mathrm{T}}(45.9 \%$ of total cellular fatty acids). The fatty acid profile of MB $1871^{\mathrm{T}}$ resembles those of other type strains of Paenibacillus species, but there are significant differences in the proportions of anteiso$\mathrm{C}_{15: 0}$ and iso- $\mathrm{C}_{15: 0}$ (Table 1).

The strains were found to be Gram-variable or Gramnegative, aerobic and motile rods. They formed ellipsoidal or cylindrical spores that lay paracentrally or subterminally in slightly swollen sporangia (Supplementary Fig. B). On TSA plates, the strains formed discrete colonies and occasionally formed spreading growth reminiscent of Paenibacillus alvei. Most of the strains clustered together at $87 \cdot 5 \%$ similarity in a UPGMA cluster analysis (not shown) based upon their biochemical reactions, and this cluster merged with other species of Paenibacillus, including $P$. lautus, $P$. macerans and $P$. polymyxa, at $80 \%$ similarity. Two strains, MB 1868 and MB 2044, gave weak reactions in the biochemical tests and did not group with other Paenibacillus species, but with the type strain of Bacillus lentus; this misallocation could be attributed entirely to the weakness of their reactions in the API 50CHB gallery, rather than to them having different patterns of carbohydrate utilization. These results indicate that, although the majority of the milk isolates form a group phenotypically distinct from established species of Paenibacillus, weakly reacting strains may be misidentified if phenotypic tests alone are relied upon for identification (see Table 2).

The genotypic and phenotypic data showed that the 19 novel isolates form a homogeneous group that is different from all other related species within the genus Paenibacillus. Therefore, they represent a novel species of the genus Paenibacillus, for which we propose the name Paenibacillus lactis sp. nov.
Table 2. Characters that distinguish $P$. lactis sp. nov. from related species

Species: 1, P. lactis sp. nov. (data from 12 strains from this study); 2, P. lautus (5 strains; data from Alexander \& Priest, 1989); 3, P. glucanolyticus (11 strains; Alexander \& Priest, 1989); 4, P. macerans (15 strains; Logan \& Berkeley, 1984); 5, P. polymyxa (15 strains; Logan \& Berkeley, 1984). With the exception of microscopic observations, anaerobic growth, growth temperature and casein hydrolysis, all characters were determined using tests in the API 20E and 50 CHB systems. Characters are scored as:,$+ 85-100 \%$ positive; $(+), 75-84 \%$ positive; V, variable (26-74\% positive); (-), 16-25\% positive; -, $0-15 \%$ positive. All species gave positive (acid) reactions with amygdalin, L-arabinose, cellobiose, D-fructose, galactose, gentiobiose, Dglucose, glycogen, lactose, D-mannose, mannitol, maltose, melibiose, methyl D-glucoside, methyl $\beta$-xyloside, D-raffinose, ribose, salicin, sucrose, D-trehalose, D-turanose, starch and D-xylose.

\begin{tabular}{|lccccc|}
\hline Characteristic & $\mathbf{1}$ & $\mathbf{2}$ & $\mathbf{3}$ & $\mathbf{4}$ & $\mathbf{5}$ \\
\hline Spore position & $\mathrm{S} / \mathrm{C}$ & $\mathrm{S}$ & $\mathrm{T}$ & $\mathrm{S} / \mathrm{T}$ & $\mathrm{S} / \mathrm{C}$ \\
Growth at $50^{\circ} \mathrm{C}$ & + & - & - & $\mathrm{V}$ & - \\
Anaerobic growth & - & + & + & + & + \\
Casein hydrolysis & - & - & $(+)$ & - & + \\
Citrate utilization & - & - & $(+)$ & - & - \\
Urease & - & + & - & - & - \\
Voges-Proskauer & $(-)$ & + & - & $\mathrm{V}$ & + \\
Gelatin hydrolysis & - & - & $(+)$ & $\mathrm{V}$ & + \\
Acid from: & & & & & \\
$\quad$ D-Arabinose & $\mathrm{V}$ & - & - & + & - \\
Arbutin & $(-)$ & + & + & + & + \\
Glycerol & - & + & $(+)$ & + & + \\
Inulin & - & $\mathrm{V}$ & + & + & $(+)$ \\
Methyl D-mannoside & - & - & + & + & $\mathrm{V}$ \\
$N$-Acetylglucosamine & + & + & + & $\mathrm{V}$ & $\mathrm{V}$ \\
Rhamnose & - & - & - & + & $\mathrm{V}$ \\
\hline
\end{tabular}

${ }^{\star} \mathrm{C}$, Central/paracentral; s, subterminal; $\mathrm{T}$, terminal.

Strains of this novel species were isolated from both raw and heat-treated milk. Moreover, we detected a clonal relationship between a raw-milk strain (MB 1868) and isolates from a contaminated lot of UHT milk. A possible contamination route from raw milk on the dairy farm to heat-treated milk in the dairy is therefore not implausible. The fact that some of these strains were present jointly with B. sporothermodurans spores, known for its extreme heat resistance (Huemer et al., 1998), in several UHT-milk packages from different processing lines indicates that, by analogy, spores of the UHT isolates of this novel species might be capable of surviving severe heat treatment and, as a result, affecting the keeping quality or safety of food products.

\section{Description of Paenibacillus lactis sp. nov.}

Paenibacillus lactis [lac'tis. L. gen. n. lactis from milk, referring to milk (and its environment on the dairy farm) as the principal isolation source]. 
Cells are single, straight and round-ended, motile rods, that may occasionally be slightly tapered and curved. Gramnegative or Gram-variable. Cell diameter is $0.6-0.9 \mu \mathrm{m}$ and cell length is 3-6 $\mu \mathrm{m}$. Endospores are ellipsoidal or cylindrical, are located subterminally and occasionally paracentrally and usually swell the sporangia. Colonies grown for 4 days on TSA at $30^{\circ} \mathrm{C}$ are opaque, creamcoloured, slightly convex and round, with rough or spreading transparent edges and with eggshell surface texture. Motile microcolonies may spread across the surface of the agar and rotate in a clockwise direction. Colony diameter is $1-2 \mathrm{~mm}$. Aerobic. Maximum temperature for growth lies between 50 and $55^{\circ} \mathrm{C}$ and the optimum temperature lies between 30 and $40{ }^{\circ} \mathrm{C}$. Optimum $\mathrm{pH}$ for growth is $7 \cdot 0$; the minimum $\mathrm{pH}$ is between $5 \cdot 0$ and $6 \cdot 0$ and the maximum $\mathrm{pH}$ between 10.5 and 11 . Casein is not hydrolysed. In the API 20E strip, $o$-nitrophenyl $\beta$-Dgalactopyranoside hydrolysis is positive. Nitrate reduction is variable and Voges-Proskauer reaction is negative or weak, while reactions for arginine dihydrolase, lysine decarboxylase, ornithine decarboxylase, citrate utilization, hydrogen sulphide production, urease, tryptophan deaminase, indole production and hydrolysis of gelatin are negative. In the API $50 \mathrm{CH}$ gallery using the $\mathrm{CHB}$ suspension medium, hydrolysis of aesculin is positive and acid is produced without gas from the following carbohydrates: amygdalin, L-arabinose, arbutin, D-cellobiose, D-fructose, D-glucose, glycogen, lactose, maltose, mannitol, D-mannose, D-melibiose, D-raffinose, ribose, starch, sucrose, D-trehalose, D-turanose and D-xylose. Occasional strains give weak reactions with the following substrates: amygdalin, L-arabinose, arbutin, D-cellobiose, D-fructose, D-glucose, lactose, maltose, mannitol, D-mannose, D-melibiose, D-raffinose, sucrose, D-turanose and D-xylose. Production of acid without gas is strain-dependent for D-arabinose, L-fucose, galactose, gentiobiose, gluconate, D-melezitose, methyl D-glucoside, methyl xyloside, $\mathrm{N}$-acetylglucosamine and salicin. Acid is not produced from adonitol, D-arabitol, L-arabitol, dulcitol, erythritol, D-fucose, glycerol, inulin, 2-keto-D-gluconate, 5-keto-Dgluconate, D-lyxose, meso-inositol, methyl D-mannoside, rhamnose, sorbitol, L-sorbose, D-tagatose, L-xylose or xylitol. Of the variable results, the type strain was positive for D-arabinose, L-fucose, galactose, gentiobiose, gluconate, D-melezitose, methyl xyloside, $N$-acetylglucosamine and salicin and was weakly positive for methyl D-glucoside. Nitrate reduction is weak and Voges-Proskauer reaction is negative. The major cellular fatty acids are (means of 10 strains): anteiso- $\mathrm{C}_{15: 0}(38 \cdot 5 \pm 5 \cdot 3 \%$ of total cellular fatty acids), $\mathrm{C}_{16: 0}(23 \cdot 9 \pm 6 \cdot 7)$, iso- $\mathrm{C}_{15: 0}(11 \cdot 1 \pm 1 \cdot 4)$, anteiso$\mathrm{C}_{17: 0}(5 \cdot 4 \pm 1 \cdot 9)$, iso- $\mathrm{C}_{16: 0}(5 \cdot 4 \pm 1 \cdot 4)$, iso- $\mathrm{C}_{17: 0}(4 \cdot 8 \pm$ $1 \cdot 2), \mathrm{C}_{16: 1} \omega 11 c(4 \cdot 3 \pm 1 \cdot 3), \mathrm{C}_{14: 0}(3 \cdot 1 \pm 1 \cdot 4)$, iso- $\mathrm{C}_{14: 0}$ $(2 \cdot 0 \pm 0 \cdot 6)$ and $\mathrm{C}_{15: 0}(1 \cdot 0 \pm 0 \cdot 7)$. Fatty acids present at less than $1 \%$ are not listed. The DNA G $+\mathrm{C}$ content varies from $51.6 \mathrm{~mol} \%$ for MB $1871^{\mathrm{T}}$ to $51 \cdot 7 \mathrm{~mol} \%$ for strains MB 1928 and MB 2035.

The type strain is $\mathrm{MB} 1871^{\mathrm{T}}$ (=LMG $21940^{\mathrm{T}}=\mathrm{DSM}$ $\left.15596^{\mathrm{T}}\right)$.

\section{Acknowledgements}

The authors are grateful to B. Christner for providing strain SB150-2B (MB 2328). We wish to thank Petra Vanmol, Liestbeth Lebbe and Elly Engels for excellent technical assistance. We are most grateful to bioMérieux SA for providing API materials and for supporting M.R.-D. P.D.V. is indebted to the National Fund for Scientific Research (Belgium) for financial support by grant G.0156.02.

\section{References}

Alexander, B. \& Priest, F. G. (1989). Bacillus glucanolyticus, a new species that degrades a variety of $\beta$-glucans. Int J Syst Bacteriol 39, 112-115.

Andersson, A., Ronner, U. \& Granum, P. E. (1995). What problems does the food industry have with the spore-forming pathogens Bacillus cereus and Clostridium perfringens? Int J Food Microbiol 28, 145-155.

Ash, C., Farrow, J. A. E., Wallbanks, S. \& Collins, M. D. (1991). Phylogenetic heterogeneity of the genus Bacillus revealed by comparative analysis of small-subunit-ribosomal RNA sequence. Lett Appl Microbiol 13, 202-206.

Ash, C., Priest, F. G. \& Collins, M. D. (1993). Molecular identification of rRNA group 3 bacilli (Ash, Farrow, Wallbanks and Collins) using a PCR probe test. Proposal for the creation of a new genus Paenibacillus. Antonie van Leeuwenhoek 64, 253-260.

Beatty, P. H. \& Jensen, S. E. (2002). Paenibacillus polymyxa produces fusaricidin-type antifungal antibiotics active against Leptosphaeria maculans, the causative agent of blackleg disease of canola. Can J Microbiol 48, 159-169.

Berge, O., Guinebretière, M.-H., Achouak, W., Normand, P. \& Heulin, T. (2002). Paenibacillus graminis sp. nov. and Paenibacillus odorifer sp. nov., isolated from plant roots, soil and food. Int J Syst Evol Microbiol 52, 607-616.

Chung, Y. R., Kim, C. H., Hwang, I. \& Chun, J. (2000). Paenibacillus koreensis sp. nov., a new species that produces an iturin-like antifungal compound. Int J Syst Evol Microbiol 50, 1495-1500.

Claus, D. \& Berkeley, R. C. W. (1986). Genus Bacillus Cohn 1872, $174^{\mathrm{AL}}$. In Bergey's Manual of Systematic Bacteriology, vol. 2, pp. 1105-1139. Edited by P. H. A. Sneath, N. S. Mair, M. E. Sharpe \& J. G. Holt. Baltimore: Williams \& Wilkins.

Coenye, T., Falsen, E., Vancanneyt, M., Hoste, B., Govan, J. R. W., Kersters, K. \& Vandamme, P. (1999). Classification of Alcaligenes faecalis-like isolates from the environment and human clinical samples as Ralstonia gilardii sp. nov. Int J Syst Bacteriol 49, 405-413.

Daane, L. L., Harjono, I., Barns, S. M., Launen, L. A., Palleroni, N. J. \& Häggblom, M. M. (2002). PAH-degradation by Paenibacillus spp. and description of Paenibacillus naphthalenovorans sp. nov., a naphthalenedegrading bacterium from the rhizosphere of salt marsh plants. Int J Syst Evol Microbiol 52, 131-139.

Elo, S., Suominen, I., Kämpfer, P., Juhanoja, J., SalkinojaSalonen, M. \& Haahtela, K. (2001). Paenibacillus borealis sp. nov., a nitrogen-fixing species isolated from spruce forest humus in Finland. Int J Syst Evol Microbiol 51, 535-545.

Ezaki, T., Hashimoto, Y. \& Yabuuchi, E. (1989). Fluorometric deoxyribonucleic acid-deoxyribonucleic acid hybridization in microdilution wells as an alternative to membrane-filter hybridization in which radioisotopes are used to determine genetic relatedness among bacterial strains. Int J Syst Bacteriol 39, 224-229.

Goris, J., Dejonghe, W., Falsen, E., De Clerck, E., Geeraerts, B., Willems, A., Top, E. M., Vandamme, P. \& De Vos, P. (2002). Diversity 
of transconjugants that acquired plasmid pJP4 or pEMT1 after inoculation of a donor strain in the A- and B-horizon of an agricultural soil and description of Burkholderia hospita sp. nov. and Burkholderia terricola sp. nov. Syst Appl Microbiol 25, 340-352.

Grau, F. H. \& Wilson, P. W. (1962). Physiology of nitrogen fixation by Bacillus polymyxa. J Bacteriol 83, 490-496.

Guinebretière, M.-H., Berge, O., Normand, P., Morris, C., Carlin, F. \& Nguyen-The, C. (2001). Identification of bacteria in pasteurized zucchini purées stored at different temperatures and comparison with those found in other pasteurized vegetable purées. Appl Environ Microbiol 67, 4520-4530.

Herman, L. M. F., Vaerewijck, M. J. M., Moermans, R. J. B. \& Waes, G. M. A. V. J. (1997). Identification and detection of Bacillus sporothermodurans spores in 1,10 , and 100 milliliters of raw milk by PCR. Appl Environ Microbiol 63, 3139-3143.

Herman, L., Heyndrickx, M. \& Waes, G. (1998). Typing of Bacillus sporothermodurans and other Bacillus species isolated from milk by repetitive element sequence based PCR. Lett Appl Microbiol 26, 183-188.

Heyndrickx, M. \& Scheldeman, P. (2002). Bacilli associated with spoilage in dairy and other food products. In Applications and Systematics of Bacillus and Relatives, pp. 64-82. Edited by R. Berkeley, M. Heyndrickx, N. Logan \& P. De Vos. Oxford: Blackwell Science.

Heyndrickx, M., Vauterin, L., Vandamme, P., Kersters, K. \& De Vos, P. (1996). Applicability of combined amplified $16 \mathrm{~S}$ rDNA restriction analysis (ARDRA) patterns in bacterial phylogeny and taxonomy. J Microbiol Methods 26, 247-259.

Huemer, I., Klijn, N., Vogelsang, H. \& Langeveld, L. (1998). Thermal death kinetics of spores of Bacillus sporothermodurans isolated from UHT-milk. Int Dairy J 8, 851-855.

Kanzawa, Y., Harada, A., Takeuchi, M., Yokota, A. \& Harada, T. (1995). Bacillus curdlanolyticus sp. nov. and Bacillus kobensis sp. nov., which hydrolyze resistant curdlan. Int J Syst Bacteriol 45, 515-521.

Logan, N. A. \& Berkeley, R. C. W. (1984). Identification of Bacillus strains using the API system. J Gen Microbiol 130, 1871-1882.

Logan, N. A., Lebbe, L., Hoste, B. \& 7 other authors (2000). Aerobic endospore-forming bacteria from geothermal environments in northern Victoria Land, Antarctica, and Candlemas Island, South Sandwich archipelago, with the proposal of Bacillus fumarioli sp. nov. Int J Syst Evol Microbiol 50, 1741-1753.

Martin, N. I., Hu, H., Moake, M. M., Churey, J. J., Whittal, R., Worobo, R. W. \& Vederas, J. C. (2003). Isolation, structural characterization, and properties of mattacin (polymyxin M), a cyclic peptide antibiotic produced by Paenibacillus kobensis M. J Biol Chem 278, 13124-13132.

Pearson, W. R. \& Lipman, D. J. (1988). Improved tools for biological sequence comparison. Proc Natl Acad Sci U S A 85, 2444-2448.

Pitcher, D. G., Saunders, N. A. \& Owen, R. J. (1989). Rapid extraction of bacterial genomic DNA with guanidium thiocyanate. Lett Appl Microbiol 8, 151-156.

Piuri, M., Sanchez-Rivas, C. \& Ruzal, S. M. (1998). A novel antimicrobial activity of a Paenibacillus polymyxa strain isolated from regional fermented sausages. Lett Appl Microbiol 27, 9-13.

Raaska, L., Sillanpaa, J., Sjoberg, A. M. \& Suihko, M. L. (2002). Potential microbiological hazards in the production of refined paper products for food applications. J Ind Microbiol Biotechnol 28, 225-231.

Rademaker, J. L. W., Hoste, B., Louws, F. J., Kersters, K., Swings, J., Vauterin, L., Vauterin, P. \& de Bruijn, F. J. (2000). Comparison of AFLP and rep-PCR genomic fingerprinting with DNA-DNA homology studies: Xanthomonas as a model system. Int J Syst Evol Microbiol 50, 665-677.

Scheldeman, P., Herman, L., Goris, J., De Vos, P. \& Heyndrickx, M. (2002). Polymerase chain reaction identification of Bacillus sporothermodurans from dairy sources. J Appl Microbiol 92, 983-991.

Seldin, L., van Elsas, J. D. \& Penido, E. G. C. (1984). Bacillus azotofixans sp. nov., a nitrogen-fixing species from Brazilian soils and grass roots. Int J Syst Bacteriol 34, 451-456.

Setlow, P. (1994). Mechanisms which contribute to the long-term survival of spores of Bacillus species. J Appl Bacteriol Symp Suppl 76, 49S-60S.

Shida, O., Takagi, H., Kadowaki, K., Nakamura, L. K. \& Komagata, K. (1997). Transfer of Bacillus alginolyticus, Bacillus chondroitinus, Bacillus curdlanolyticus, Bacillus glucanolyticus, Bacillus kobensis, and Bacillus thiaminolyticus to the genus Paenibacillus and emended description of the genus Paenibacillus. Int J Syst Bacteriol 47, 289-298.

Stackebrandt, E., Frederiksen, W., Garrity, G. M. \& 10 other authors (2002). Report of the ad hoc committee for the re-evaluation of the species definition in bacteriology. Int J Syst Evol Microbiol 52, 1043-1047.

te Giffel, M. C., Wagendorp, A., Herrewegh, A. \& Driehuis, F. (2002). Bacterial spores in silage and raw milk. Antonie van Leeuwenhoek 81, 625-630.

Vaerewijck, M. J., De Vos, P., Lebbe, L., Scheldeman, P., Hoste, B. \& Heyndrickx, M. (2001). Occurrence of Bacillus sporothermodurans and other aerobic spore-forming species in feed concentrate for dairy cattle. J Appl Microbiol 91, 1074-1084.

Vancanneyt, M., Witt, S., Abraham, W. R., Kersters, K. \& Fredrickson, H. L. (1996). Fatty acid content in whole-cell hydrolysates and phospholipid fractions of pseudomonads: a taxonomic evaluation. Syst Appl Microbiol 19, 528-540.

Versalovic, J., Schneider, M., de Bruijn, F. J. \& Lupski, J. R. (1994). Genomic fingerprinting of bacteria using repetitive sequence-based polymerase chain reaction. Methods Mol Cell Biol 5, 25-40.

von der Weid, I., Duarte, G. F., van Elsas, J. D. \& Seldin, L. (2002). Paenibacillus brasilensis sp. nov., a novel nitrogen-fixing species isolated from the maize rhizosphere in Brazil. Int J Syst Evol Microbiol 52, 2147-2153.

Wayne, L. G., Brenner, D. J., Colwell, R. R. \& 9 other authors (1987). Report of the ad hoc committee on reconciliation of approaches to bacterial systematics. Int J Syst Bacteriol 37, 463-464.

Willems, A., Doignon-Bourcier, F., Goris, J., Coopman, R., de Lajudie, P., De Vos, P. \& Gillis, M. (2001). DNA-DNA hybridization study of Bradyrhizobium strains. Int J Syst Evol Microbiol 51, 13151322.

Witz, D. F., Detroy, R. W. \& Wilson, P. W. (1967). Nitrogen fixation by growing cells and cell-free extracts of the Bacillaceae. Arch Mikrobiol 55, 369-381. 